\title{
Serum Chloride Measurement
}

National Cancer Institute

\section{Source}

National Cancer Institute. Serum Chloride Measurement. NCI Thesaurus. Code C61021.

A quantitative measurement of the amount of chloride present in a sample of serum. 